\title{
Government public policy, regulatory intervention, and their impact on IPO underpricing: the case of Malaysian IPOs
}

\begin{abstract}
This study examines the impact of government initial public offering (IPO) regulation intending on promoting public policy. The study examines the results of the implementation of a Malaysian government policy in 1976, which mandated that at least 30 percent of any new shares on an IPO offer be sold to the indigenous Bumiputera population or to mutual funds owned by them. The study examined the short-run and long-run underpricing of Malaysian IPOs and found that Malaysian IPOs are highly underpriced compared to IPOs in developing countries, creating a market microstructure effect. It also confirmed that the Malaysian government's regulatory intervention in spite of noble public policy intentions appeared to be the significant factor for the emergence of an average first-day underpricing increase of Malaysian IPOs by 61 percent during the period after the regulatory economic policy was instituted. Furthermore, the study found that this high underpricing persists even for the long run, in contrast to the long-run performance of IPOs in the United States.
\end{abstract}

